\title{
High Temperature Fast Response Aerodynamic Probe
}

\section{Doctoral Thesis}

Author(s):

Lenherr, Christian

Publication date:

2011

Permanent link:

https://doi.org/10.3929/ethz-a-006344311

Rights / license:

In Copyright - Non-Commercial Use Permitted 


\title{
High Temperature \\ Fast Response Aerodynamic Probe
}

\author{
DISSERTATION \\ Submitted to \\ ETH ZURICH \\ for the degree of \\ DOCTOR OF SCIENCES
}

\author{
presented by \\ CHRISTIAN LENHERR \\ Dipl.-Ing. ETH \\ born February 25, 1978 \\ citizen of \\ Gams (SG)
}

accepted on the recommendation of

Prof. Dr. Reza S. Abhari, examiner

Prof. Dr. Hyung Gyu Park, co-examiner

Dr. Anestis I. Kalfas, co-examiner

Zurich 2010 


\section{Abstract}

In the last decade, significant improvements have been achieved in the development of new materials and in cooling techniques in the field of turbomachinery. The main driver for the focus on such topics is due to the trend of higher turbine inlet temperatures. This leads to a larger amount of work per unit mass flow and an improved weight-to-power ratio of engines. However, under these severe flow conditions, it is of even more importance to be able to measure unsteady flow phenomena, in order to improve our understanding of loss generation mechanisms.

The objective of this work is therefore to design, build and evaluate a new Fast Response Aerodynamic Probe with a higher upper temperature limit (533K) compared to traditional unsteady pressure probe techniques, often limited to temperatures around 390K. Such a new probe, with a higher upper temperature limit therefore opens up a wide field of applications, such as measurements in centrifugal compressors at design point, or in the first compressor stages of axial machines. The development of the probe is therefore motivated by the need for unsteady measurement techniques that are capable of withstanding the harsh environment of turbomachines.

The new probe is comprised of a pair of piezoresistive pressure sensors that measure the unsteady pressure and the steady temperature, respectively. Special care is taken to account for effects related to the higher temperature levels. Furthermore, possible probe shaft vibrations when operating the probe at high temperatures are taken into account in order to achieve a robust probe design.

The thesis details the operating principle, the design and fabrication of the high temperature fast response aerodynamic probe (FRAP-HT), as well as the integration of additional sensors in order to thermally manage the probe and to monitor possible probe shaft vibrations.

Major challenges related to topics such as sensor technology, signal conditioning, material science, packaging technology as well as electrical connections are addressed in the thesis.

The calibration procedure, the dynamic response, the measurement system and the measurement uncertainty analysis for the new probe are described in detail. Furthermore, in order to be able to apply the probe in harsh flows of any kind, several subcomponent systems, such as a sensor calibration oven and a sensor characteristic test device working in the high temperature range are 
required. Their design and evaluation is as well detailed in this thesis.

In order to demonstrate the measurement principle and to detail the unsteady flow in severe flow conditions, the new probe is applied in an axial research turbine equipped with a hot-streak generator. Furthermore measurements in a centrifugal compressor facility, in order to first time ever detail unsteady measurements at the design point of the facility are performed and discussed.

A comparison between measurements using the newly developed high temperature probe against various well-established steady and unsteady measurement techniques is performed. There is good agreement between all the techniques and therefore the new probe concept was proven to be applicable. The minor variations between the measurements of the different probe techniques might be related to combinations of different effects such as, wall proximity effects, blockage effects due to the difference in the probe diameter and relative sensor position, high total pressure gradients near the endwalls and a lower signal-to-noise ratio of the standard FRAP for elevated flow temperatures compared to the new FRAP-HT.

Based on the validation results of the new FRAP-HT probe and due to its higher degree of robustness it is concluded that the newly designed probe allows one to successfully conduct measurements in the harsh environment of real turbomachinery, such as at the exit of axial compressors as well as in a wide spectrum of centrifugal compressors. The probe therefore is a major contribution both to the turbomachinery community as well as for future developments of unsteady probe technology. 


\section{Résumé}

Lors de la dernière décennie, d'importants progrès ont été réalisés dans le développement de nouveaux matériaux haute température ainsi que dans les techniques de refroidissement dédiées à la turbomachine. Ceci dans l'optique d'opérer à des températures d'entrée de turbine plus élevées. Les objectifs principaux étant de pouvoir générer un plus grand travail par unité de débitmasse, ainsi que d'améliorer le ratio poids/puissance des turboréacteurs. Néanmoins, il est d'autant plus important de pouvoir réaliser des mesures d'écoulements instationnaires. Afin d'améliorer notre compréhension des mécanismes de pertes aérodynamiques liées à ces conditions d'écoulements complexes.

L'objectif de cette thèse est de développer et d'évaluer une nouvelle sonde rapide de mesure aérodynamique, pouvant opérer à des températures d'écoulement plus élevées (533K) que les sondes rapides traditionnelles se limitant à des températures maximales d'utilisation de 390K. Cette nouvelle sonde haute température permet d'étendre les prises de mesures au point nominal de fonctionnement de compresseurs radiaux, ainsi que dans les premiers étages de compressions de machines axiales. De manière générale, la motivation principale est le besoin de technique de mesure en temps réels applicables aux écoulements rigoureux des turbomachines.

La nouvelle sonde est équipée d'une paire de capteurs de pression piézorésistif, permettant la mesure de pression instationnaire, ainsi que la mesure de température stationnaire. Un soin particulier a été apporté aux effets thermiques liés à l'utilisation à haute température. De plus, les effets vibratoires induits par la fréquence propre de la sonde sur la mesure de pression ont été considérés de manière à obtenir un design robuste de la sonde.

La thèse fournit une explication détaillée du principe de fonctionnement de la sonde. Incluant la conception et la fabrication de la sonde rapide aérodynamique haute température (FRAP-HT); ainsi que l'intégration de capteurs additionnels nécessaires à la gestion thermique et au monitoring des vibrations induites.

Les défis principaux liés aux thèmes aussi divers que la technologie des capteurs, le conditionnement du signal, la science des matériaux et les micros assemblages sont abordés dans la thèse.

La procédure de calibration, l'étalonnage dynamique, le système de mesure et le calcul d'incertitude sont décris en détail. De plus, la thèse inclut une 
description exhaustive des stands de calibrations nécessaires à l'étalonnage de la sonde, et permettant de procédé à des mesures instationnaires dans des écoulements extrêmes et de caractéristiques très diverses.

La nouvelle technique de mesure a été validée dans une turbine axiale de recherche équipée d'un générateur de flux chaud. De plus les mesures d'écoulement instationnaire réalisé pour la première fois au point nominal de fonctionnement d'un compresseur radial sont présentées et analysées.

Les mesures réalisées avec la sonde haute température ont été comparées avec des techniques de mesure traditionnelles. Le haut niveau de concordance des résultats permet de conclure à la validité de la nouvelle technique au niveau stationnaire et instationnaire. Les faibles divergences observées entre les diverses techniques de mesure appliquées, peuvent être attribuées à la combinaison des facteurs suivants: effets de proximité de surface, différence de taille de sondes et de placement relatif des capteurs, gradients de pression prononcés proche de la paroi et niveau de bruit de mesure réduit de la FRAPHT à haute température comparé aux sondes aérodynamique traditionnelles FRAP.

Sur la base des résultats de validation de la sonde FRAP-HT et sur sa capacité démontrée à mesurer dans divers écoulement éprouvant de turbomachines. Il peut être conclut que la sonde FRAP-HT offre une opportunité unique d'accomplir des prises de mesures instationnaires dans une large gamme de compresseur radiaux et axiaux, ainsi que dans un grand nombre des stands de recherche d'aérodynamique à températures élevées. De manière générale le développement de la FRAP-HT peut être considérer comme une contribution majeure pour la communauté des turbomachinistes et pour le développement future de nouvelles sondes aérodynamiques rapides. 